\title{
Inhibition of Plasminogen Activator Inhibitor-1 Activity by Two Diketopiperazines, XR330 and XR334 Produced by Streptomyces sp.
}

\author{
Justin Bryans, Peter Charlton*, Inês Chicarelli-Robinson, Mark Collins, \\ Richard Faint, Chris latham, Ian Shaw \\ and SAlly TREW \\ Xenova Limited,
}

240 Bath Road, Slough, Berkshire, SL1 4EF, U.K.

(Received for publication May 27, 1996)

\begin{abstract}
Two diketopiperazines, XR334 (1) and the novel compound XR330 (2), were isolated from the lyophilised biomass of an unidentified Streptomyces $\mathrm{sp}$. Their structures were elucidated on the basis of spectroscopic studies and confirmed by chemical synthesis. Both compounds inhibited plasminogen activator inhibitor-1 activity in an amidolytic assay of tissue plasminogen activator mediated plasmin generation. Compound 1 also enhanced fibrinolysis ex vivo and protected against thrombus formation in the rat. These diketopiperazines represent the first low molecular weight inhibitors of plasminogen activator inhibitor-1, a physiological regulator of fibrinolysis
\end{abstract}

Thrombotic and thromboembolic diseases are major causes of hospitalisation and death in the developed world. A key event in the regulation of thrombus formation and clearance is tissue plasminogen activator (tPA) generation of plasmin ${ }^{1}$. tPA activity is itself regulated primarily by the fast-acting inhibitor plasminogen activator inhibitor-1 (PAI-1), a member of the serine protease inhibitor (serpin) superfamily of protease inhibitors ${ }^{2)}$. The PAI-1 cDNA encodes a 402 amino acid protein including a 23 amino acid signal peptide with a predicted, glycosylated mass of $52 \mathrm{kD}^{3)}$. PAI-1 inhibition of tPA is mediated through a "bait" residue (Arg 346Met 347) which mimics the normal substrate ${ }^{4}$. The physiological importance of PAI-1 has been demonstrated in transgenic mice which express high levels of human PAI-1 and suffer severe venous thrombosis ${ }^{5)}$. An increase in the plasma concentration of PAI- 1 has been proposed as a risk factor in thrombotic disease ${ }^{6}$. During a screening programme for inhibitors of PAI-1 activity we discovered a series of low molecular weight, nonpeptidyl inhibitors of PAI-1 from fermentation of an unidentified Streptomyces sp. Two examples of this series, XR334 (1) and the novel compound XR330 (2) were purified from the mycelium ${ }^{7}$ (Fig. 1). A series of closely related metabolites has been isolated from Streptomyces thioluteus including $\mathbf{1}^{8}$. Several of these compounds were reported to show weak antibacterial activity. Synthetic analogues of 1 have also been reported previously ${ }^{9 \sim 11)}$. Related diketopiperazines with putative cytotoxic activity have also been isolated from Micromonospora neiheunsis ${ }^{12}$. We report here an important new biologi-
Fig. 1. Structures of XR334, XR330, XR333 and XR335.<smiles></smiles>

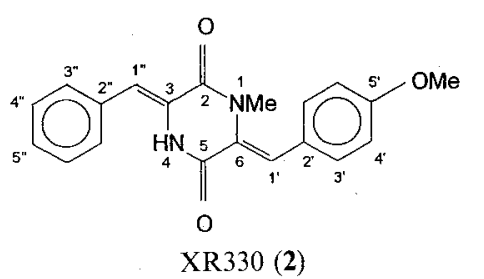<smiles>COc1ccc(/C=c2\c(=O)n(C)c(=Cc3ccccc3)c(=O)n2C)cc1</smiles>

XR333 (3)

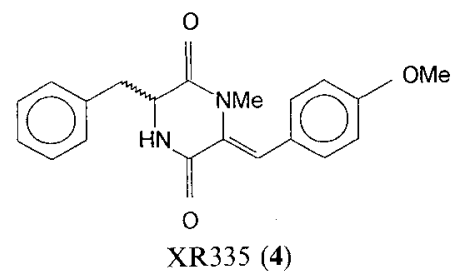

Structures of $\mathbf{1}$ and $\mathbf{2}$ isolated from the culture biomass of Streptomyces sp. and the structure confirmed by synthesis. Structures for two additional minor metabolites, 3 and $\mathbf{4}$, are proposed. 
cal activity for 1 and the related analogue 2. These diketopiperazines provide the first low molecular weight inhibitors of the physiologically important serpin, PAI-1. In this paper we describe the fermentation, isolation, structure elucidation and synthesis of these compounds together with the preliminary biological evaluation of $\mathbf{1}$.

\section{Results}

\section{Fermentation}

Streptomyces sp. X01/4/100 is an unidentified streptomycete isolated from a soil sample collected in the United Kingdom. It has been deposited under the Budapest Treaty at the National Collection of Industrial and Marine Bacteria Ltd. under the accession number NCIMB 40485.

Table 1. Taxonomic studies of Streptomyces sp. X01/4/100.

\begin{tabular}{|c|c|}
\hline Character & $\mathrm{X} 01 / 4 / 100$ \\
\hline Spore chain & Rectiflexibiles \\
\hline Number of spores in chain & $20 \sim 50$ \\
\hline Spore surface & Smooth \\
\hline Spore colour & Red \\
\hline Spore dimensions (widest points) & $0.6 \times 1 \mu \mathrm{m}$ \\
\hline Fragmentation of mycelium & None \\
\hline Reverse pigmentation & Yellow/brown \\
\hline Melanin production & No \\
\hline \multicolumn{2}{|l|}{ Substrate utilisation: } \\
\hline Adonitol & + \\
\hline Cellobiose & - \\
\hline D-Fructose & + \\
\hline meso-Inositol & - \\
\hline Inulin & - \\
\hline Mannitol & + \\
\hline Raffinose & + \\
\hline Rhamnose & - \\
\hline D-Xylose & - \\
\hline DL- $\alpha$-Aminobutyric acid & + \\
\hline L-Histidine & + \\
\hline L-Hydroxyproline & - \\
\hline \multicolumn{2}{|l|}{ Degradation of: } \\
\hline Allantoin & + \\
\hline Arbutin & + \\
\hline Xanthine & - \\
\hline Pectin & - \\
\hline Lecithin & - \\
\hline Nitrate Reduction & - \\
\hline Hydrogen sulphide production & + \\
\hline Tolerance of sodium azide $(0.01 \% \mathrm{w} / \mathrm{v})$ & + \\
\hline Tolerance of sodium chloride $(7 \% \mathrm{w} / \mathrm{v})$ & + \\
\hline Tolerance of phenol $(0.1 \% \mathrm{w} / \mathrm{v})$ & + \\
\hline Growth temperature range & $20 \sim 35^{\circ} \mathrm{C}$ \\
\hline Resistance to neomycin $(50 \mu \mathrm{g} / \mathrm{ml})$ & - \\
\hline Resistance to rifampicin $(50 \mu \mathrm{g} / \mathrm{ml})$ & - \\
\hline Antibiosis to Aspergillus niger LIV 131 & + \\
\hline $\begin{array}{l}\text { Antibiosis to Bacillus subtilis NCIMB } \\
3610\end{array}$ & + \\
\hline $\begin{array}{l}\text { Antibiosis to Streptomyces murinus ISP } \\
5091\end{array}$ & + \\
\hline
\end{tabular}

Taxonomic studies on Streptomyces sp. X01/4/100 were carried out according to the recognised methodology of Williams et al. ${ }^{13)}$ recommended in BergeY's Manual of Systematic Bacteriology Volume 4. The data obtained from these investigations, summarised in Table 1 , do not clearly identify the organism with any of the species groups of the genus Streptomyces defined by WILLIAMS et al. $^{13,14)}$.

A cryovial containing $1 \mathrm{ml}$ of a suspension of biomass of Streptomyces sp. X01/4/100 in $10 \%$ glycerol was retrieved from storage at $-135^{\circ} \mathrm{C}$ and $0.5 \mathrm{ml}$ of this used to inoculate $20 \mathrm{ml}$ of medium $\mathrm{S}$ in a $250-\mathrm{ml}$ Erlenmeyer flask. Medium S consisted of D-glucose, malt extract, yeast extract, glycerol, soyabean peptone, $\mathrm{NaCl}, \mathrm{CaCO}_{3}$, Junlon PW100 (Honeywill \& Stein), Tween 80 (Sigma), $\mathrm{pH}$ 7. This culture was incubated at $28^{\circ} \mathrm{C}$ on an orbital shaker at $240 \mathrm{rpm}$ for 4 days before another $20 \mathrm{ml}$ of medium $\mathrm{S}$ was added and the incubation was continued under the same conditions for a further 4 days. At this point the $40 \mathrm{ml}$ culture was used to inoculate 3.5 litres of medium $\mathrm{S}$ in a 4.5-litre stirred fermenter which was then incubated at $28^{\circ} \mathrm{C}, 350 \mathrm{rpm}$ for 4 days with an aeration rate of 0.5 volumes of air per volume of fermentation per minute (vvm). The $\mathrm{pH}$ of this culture was controlled to between 5.5 and 6.5. The resultant culture was used to inoculate 50 litres of medium $P$ in a 75 -litre stirred fermenter. Medium $\mathrm{P}$ contained MOPS, proline, sucrose, $\mathrm{NaCl}, \mathrm{K}_{2} \mathrm{HPO}_{4}, \mathrm{MgSO}_{4} \cdot 7 \mathrm{H}_{2} \mathrm{O}, \mathrm{CaCl}_{2} \cdot 2 \mathrm{H}_{2} \mathrm{O}$, $\mathrm{FeSO}_{4} \cdot 7 \mathrm{H}_{2} \mathrm{O}$, trace elements solution, vitamin mixture, $\mathrm{pH}$ 7. The trace elements solution consisted of $\mathrm{ZnSO}_{4}$. $7 \mathrm{H}_{2} \mathrm{O}, \mathrm{KI}, \mathrm{MnSO}_{4} \cdot 4 \mathrm{H}_{2} \mathrm{O}, \mathrm{H}_{3} \mathrm{BO}_{3}, \mathrm{CuSO}_{4} \cdot 5 \mathrm{H}_{2} \mathrm{O}$, $\mathrm{Na}_{2} \mathrm{MoO}_{4} \cdot 2 \mathrm{H}_{2} \mathrm{O}, \mathrm{CoCl}_{2} \cdot 6 \mathrm{H}_{2} \mathrm{O}, \mathrm{H}_{2} \mathrm{SO}_{4}$. The vitamin mixture consisted of thiamine $\mathrm{HCl}$, riboflavin, sodium pantothenate, nicotinic acid, pyridoxine $\mathrm{HCl}$, thioctic acid, folic acid, biotin, cyanocobalamin, potassium $p$ aminobenzoate, vitamin $K_{1}$. The fermentation was carried out for 5 days at $28^{\circ} \mathrm{C}$ with stirring at $250 \sim 500$ $\mathrm{rpm}$ and aeration at $0.5 \mathrm{vvm}$, the $\mathrm{pH}$ was controlled at between 5.75 and 6.5 and antifoam A (Sigma) was used to control foaming.

\section{Effect of Concentration of Medium $\mathrm{P}$ on Production of $\mathbf{1}$ and $\mathbf{2}$}

Small scale $(10 \mathrm{ml})$ cultures were used to investigate how the concentration of medium and $\mathrm{C}: \mathrm{N}$ ratio affected the production of these metabolites.

The results shown in Fig. 2 clearly show that reduction in the concentration of medium $P$ had a stimulatory effect on the production of both $\mathbf{1}$ and $\mathbf{2}$. Reduction of the medium concentration to $75 \%$ or $50 \%$ that of the control 
Fig. 2. Effect of medium concentration on the specific production of $\mathbf{1}(\mathrm{a})$ and $2(\mathrm{~b})$.

$\square 200 \%, \circ 150 \%, \Delta 100 \%, \nabla 75 \%, \diamond 50 \%$.

(a)

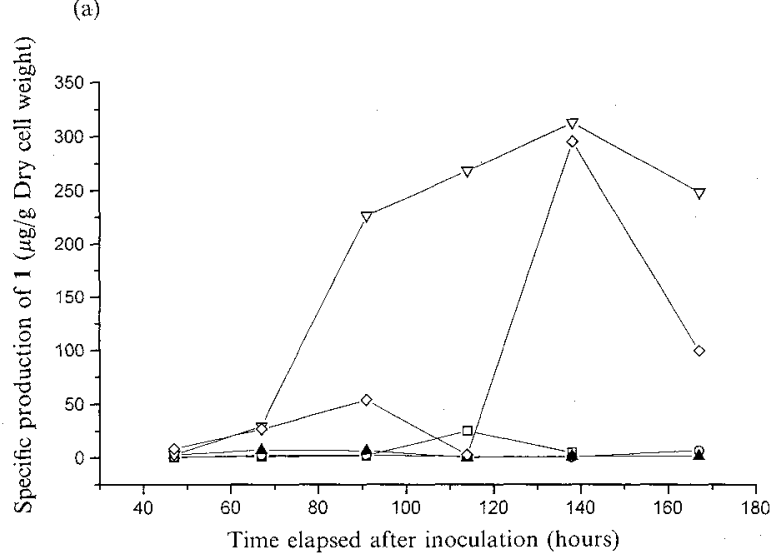

(b)

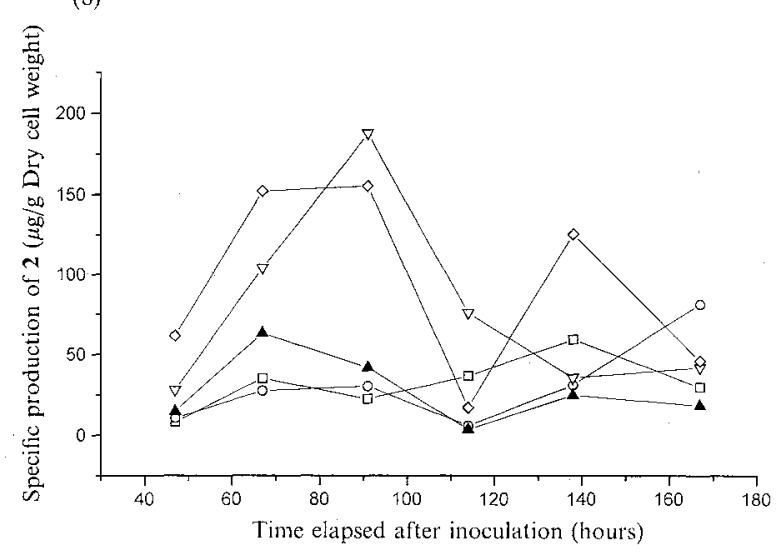

led to 2.96 and 2.4 fold increases respectively in the production of 2 (Fig. 2b), the increase in production in $75 \%$ medium resulting in a 2 fold increase in product titre despite a reduced biomass. The effect on specific production of 1 was far more marked with 45.5 and 43 -fold increases observed with $75 \%$ and $50 \%$ medium concentrations respectively (Fig. 2a). This increase in the production of these metabolites may be linked to the greater availability of oxygen per unit biomass in the diluted media. Observations from the large scale fermentations of this organism (data not shown) support this hypothesis. The highest titres were achieved in cultures where the dissolved oxygen tension (DOT) remained above $50 \%$.

\section{Effect of C: N Ratio on Production of $\mathbf{1}$ and $\mathbf{2}$}

Fermentations were carried out using variations of $75 \%$ medium $P$ with $\mathrm{C}: \mathrm{N}$ ratios increased or decreased from the original value of $13.8: 1$. The modifications were made through increasing or decreasing the concentra-
Fig. 3. Production of $\mathbf{1}$ and $\mathbf{2}$.

Maximum measured titres over 110 hours on media with different $\mathrm{C}: \mathrm{N}$ ratios.

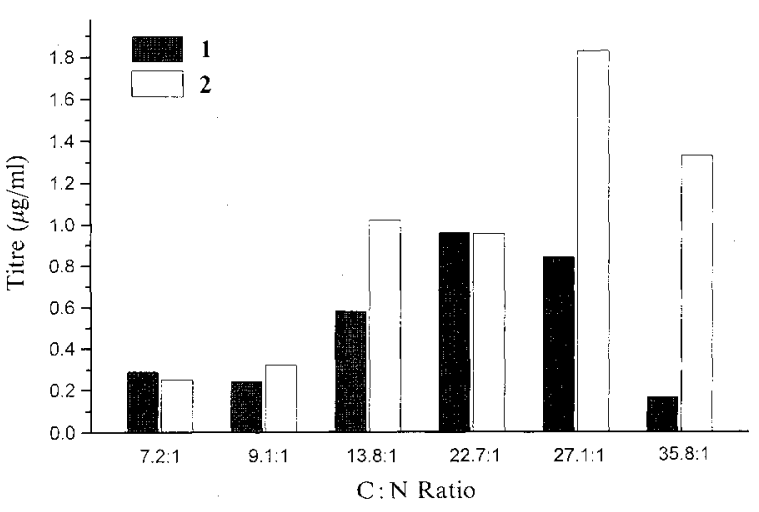

tions of sucrose and glycerol in the medium, concentrations of all other medium components remained constant.

Fig. 3 shows the maximum titre of $\mathbf{1}$ and $\mathbf{2}$ obtained in the different media after 110 hours. A reduction in the $\mathrm{C}: \mathrm{N}$ ratio from 13.8:1 decreased the titres achieved, whereas increasing it to $27: 1$ increased the titres. The decreased titres at the lower $\mathrm{C}: \mathrm{N}$ ratios $(9.1: 1$ and $7.2: 1)$ correlated well with a reduction in the production rate of the metabolites (data not shown). In contrast, the higher $\mathrm{C}: \mathrm{N}$ ratio media did not increase the initial production rate but these conditions appeared to delay cell lysis which resulted in a prolonged production phase (data not shown). The optimum $\mathrm{C}: \mathrm{N}$ ratio for this system was $27.1: 1$ as a further increase in the ratio led to a lower production rate and a lower titre at harvest.

\section{Isolation}

Compounds $\mathbf{1}$ and $\mathbf{2}$ were isolated from the mycelium by solvent extraction and purified by chromatography. Details of the isolation procedure are described in the experimental section.

\section{Physico-chemical Properties and Structure Elucidation}

The compounds were characterised by standard physical techniques, including UV, MS, IR and NMR spectra. The physico-chemical properties of $\mathbf{1}$ and $\mathbf{2}$ are summarised in Table 2. The ${ }^{13} \mathrm{C}$ and ${ }^{1} \mathrm{H}$ NMR data of $\mathbf{2}$ are summarised in Table 3.

In the case of compound $\mathbf{2}$ a molecular formula of $\mathrm{C}_{20} \mathrm{H}_{18} \mathrm{~N}_{2} \mathrm{O}_{3}$ was deduced from accurate mass measurements on the molecular ion. The ${ }^{1} \mathrm{H}$ and ${ }^{1} \mathrm{H}-{ }^{1} \mathrm{H}$ COSY NMR spectra included two three-proton singlets corresponding to the presence of two methyl groups attached 
Table 2. Physico-chemical properties of $\mathbf{1}$ and $\mathbf{2}$.

\begin{tabular}{lll}
\hline & \multicolumn{1}{c}{1} & \multicolumn{1}{c}{$\mathbf{2}$} \\
\hline Appearance & White/yellow powder & White/yellow powder \\
Molecular weight & 320 & 334 \\
Molecular formula & $\mathrm{C}_{19} \mathrm{H}_{16} \mathrm{~N}_{2} \mathrm{O}_{3}$ & $\mathrm{C}_{20} \mathrm{H}_{18} \mathrm{~N}_{2} \mathrm{O}_{3}$ \\
HREI-MS $(m / z)$ & & \\
Calcd: & 320.1161 & 334.1317 \\
Found: & 320.1164 & 334.1320 \\
UV MeOH $\lambda_{\text {max }} \mathrm{nm}$ & 330, end absorbance & 350, end absorbance \\
IR $v_{\max }(\mathrm{KBr}) \mathrm{cm}^{-1}$ & $3200,3050,1735,1720,1400$, & $3200,3050,1720,1620,1390$, \\
& $1230,1010,730$ & 1350,750 \\
\hline
\end{tabular}

Table 3. ${ }^{13} \mathrm{C}$ and ${ }^{1} \mathrm{H}$ NMR data of 2 in $\mathrm{CDCl}_{3}\left(30^{\circ} \mathrm{C}\right)$.

\begin{tabular}{crl}
\hline Position & \multicolumn{1}{c}{$\delta_{\mathrm{C}}{ }^{\mathrm{a}}$} & $\delta_{\mathrm{H}}{ }^{\mathrm{b}}$ \\
\hline 2 & 159.63 & \\
3 & 125.99 & \\
4 & & $8.05(1 \mathrm{H}, \mathrm{brs})$ \\
5 & $159.88^{\mathrm{c}}$ & \\
6 & 128.95 & \\
$1^{\prime}$ & 121.30 & $7.25(1 \mathrm{H}, \mathrm{s})$ \\
$2^{\prime}$ & 125.93 & \\
$3^{\prime}$ & 131.05 & $7.24(2 \mathrm{H}, \mathrm{d}, J=8.8 \mathrm{~Hz})$ \\
$4^{\prime}$ & 113.79 & $6.93(2 \mathrm{H}, \mathrm{d}, J=8.6 \mathrm{~Hz})$ \\
$5^{\prime}$ & $159.80^{\mathrm{c}}$ & \\
$1^{\prime \prime}$ & 116.95 & $7.07(1 \mathrm{H}, \mathrm{s})$ \\
$2^{\prime \prime}$ & 132.94 & \\
$3^{\prime \prime}$ & 128.45 & $7.42(2 \mathrm{H}, \mathrm{m})$ \\
$4^{\prime \prime}$ & 129.35 & $7.42(2 \mathrm{H}, \mathrm{m})$ \\
$5^{\prime \prime}$ & 128.71 & $7.36(1 \mathrm{H}, \mathrm{m})$ \\
$\mathrm{N}-\mathrm{C} H_{3}$ & 36.54 & $3.05(3 \mathrm{H}, \mathrm{s})$ \\
O-CH & 55.27 & $3.83(3 \mathrm{H}, \mathrm{s})$ \\
\hline
\end{tabular}

a Chemical shifts are shown referenced to $\mathrm{CDCl}_{3}$ as 77.00 ppm.

b Chemical shifts are shown referenced to $\mathrm{CDCl}_{3}$ as 7.25 ppm.

c Assignments may be exchanged.

Fig. 4. Selected long range ${ }^{1} \mathrm{H}^{13} \mathrm{C}$ couplings observed for 2 in a COLOC experiment.

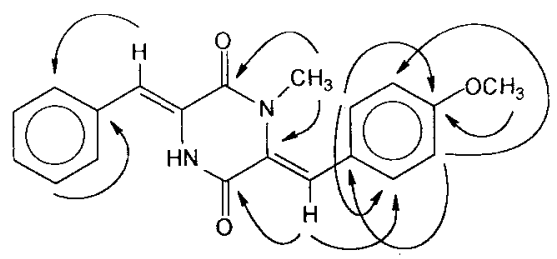

to oxygen and nitrogen respectively, a broad one proton singlet at $8.05 \mathrm{ppm}$ and revealed the presence of eleven further protons corresponding to a benzylidene and a para-substituted benzylidene group. The ${ }^{13} \mathrm{C}$ NMR sprectrum supported the above conclusions and further indicated the presence of two quaternary carbons carbons resonating at 159.63 and $159.88 \mathrm{ppm}$. The
Fig. 5. Synthesis of $\mathbf{1}$ and $\mathbf{2}$.<smiles>O=C1CNC(=O)CN1</smiles>

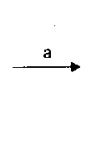<smiles>CN1CC(=O)NC1C(=O)O</smiles><smiles>COc1ccc(C=C2C(=O)NCC(=O)N2C)cc1</smiles>
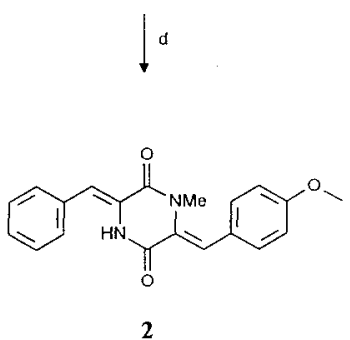

(a) $\mathrm{Ac}_{2} \mathrm{O}, 130^{\circ} \mathrm{C}, 6$ hours; $85 \%$.

(b) $\mathrm{KOtBu}$, 4-methoxybenzaldehyde, $\mathrm{tBuOH}, \mathrm{THF}, 0^{\circ} \mathrm{C}$ to room temperature, overnight; $69 \%$.

(c) $\mathrm{Na}_{2} \mathrm{CO}_{3}, \mathrm{MeI}$, DMF, room temperature, 4 days; $88 \%$.

(d) $\mathrm{Cs}_{2} \mathrm{CO}_{3}$, benzaldehyde, DMF, $80^{\circ} \mathrm{C} ; 2$ hours; $54 \%$.

(e) $\mathrm{Cs}_{2} \mathrm{CO}_{3}$, benzaldehyde, DMF, $90^{\circ} \mathrm{C}, 2$ hours; $67 \%$. structure of compound $\mathbf{2}$ was elucidated by interpretation of spectral data, including the results of DEPT, ${ }^{13} \mathrm{C}-{ }^{1} \mathrm{H}$ correlation and COLOC (COrrelation spectroscopy via LOng range Coupling) experiments. Key correlations observed in the COLOC experiment are illustrated in Fig. 4 . The structure of compound 1 was determined in similar fashion. The stereochemistry of $\mathbf{1}$ and $\mathbf{2}$ was proposed to be $3 Z, 6 Z$ based on the geometric isomer produced by $S$. thioluteus and biosynthetic grounds. The proposed structures of $\mathbf{1}$ and $\mathbf{2}$ were confirmed by synthesis. 
Fig. 6. Effect of different doses of $\mathbf{1}$ on fibrinolysis ex vivo in the rat dilute blood clot lysis time assay.

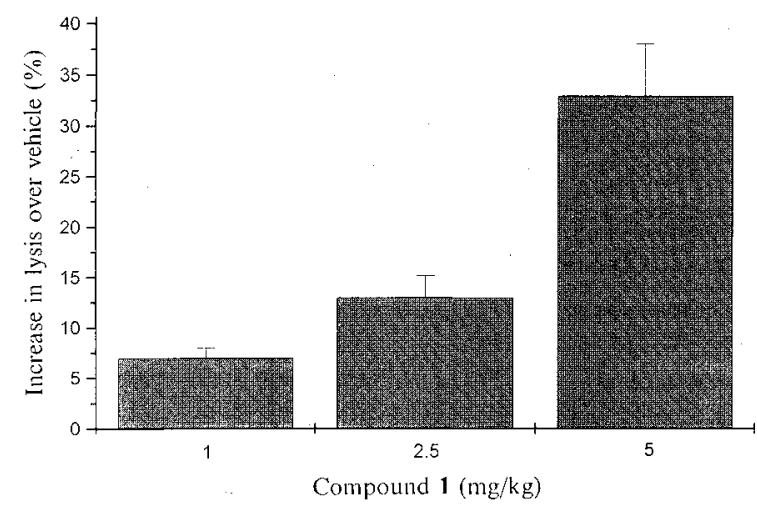

Vehicle $(10 \%$ Solutol in saline) or $1(1,2.5$ and $5 \mathrm{mg} / \mathrm{kg})$ was administered by single bolus injection via the tail vein. Data show maximum increase in lysis over vehicle control expressed as a percentage. Results indicate mean and standard error of 3 experiments.

\section{Synthesis of $\mathbf{1}$ and $\mathbf{2}$}

The synthesis of compounds $\mathbf{1}$ and $\mathbf{2}$ is outlined in Fig. 5. Details of the synthesis are described in the experimental section.

\section{Biological Activity}

\section{Chromogenic Assays}

Compounds 1 and 2 inhibited PAI-1 in an in vitro tPA-mediated plasmin generation assay (S2251) with $\mathrm{IC}_{50}$ values of $51 \pm 7 \mu \mathrm{M}$ (mean $\pm \mathrm{SE}$ ) and $c a .30 \mu \mathrm{M}$, respectively. Compound $\mathbf{1}$ was chosen to profile further and was shown to also inhibit PAI-1 in a urokinase amidolytic assay (S2444) with an $\mathrm{IC}_{50}$ value of $80 \pm 4 \mu \mathrm{M}$. Various controls were included to exclude the possibility that the diketopiperazine interfered with the substrates or acted directly on the plasminogen activators. Details of these assays are described in the experimental section.

\section{Rat Dilute Blood Clot Lysis Time Assay}

The effect of 1 on ex vivo fibrinolysis in the rat is shown in Fig. 6.

\section{Discussion}

The diketopiperazines described in this paper provide a chemical template for the design of low molecular weight inhibitors of PAI-1. The two related metabolites, including the novel compound 2, were isolated from the lyophilised biomass of an unidentified Streptomyces sp. It is probable that this family of diketopiperazine adducts are derived from phenylalanine and $O$-methyltyrosine. The structures of $\mathbf{1}$ and $\mathbf{2}$ were confirmed by total synthesis.

As part of a programme to identify additional active metabolites we assessed the effect of medium component concentration and $\mathrm{C}: \mathrm{N}$ ratio on production of $\mathbf{1}$ and $\mathbf{2}$. Dilution of the growth medium resulted in increased production of both compounds but the increase was greater for 1. It is probable that increased oxygen availability contributed to the enhanced production. A marked improvement in titre for both 1 and 2 was achieved by increasing the $\mathrm{C}: \mathrm{N}$ ratio from 13.8:1 to 27.1:1. Additional related metabolites were isolated from the biomass. The proposed structures (XR333, 3, and XR335,4) are shown in Fig. 1 but there was insufficient material for full structural confirmation.

There is a growing body of evidence that elevated PAI-1 activity is a risk factor for thromboembolic disease as a result of decreased fibrinolytic activity ${ }^{15)}$. The importance of PAI-1 is supported by recent studies utilising antibodies as PAI-1 inhibitors. In a rabbit jugular vein model an anti-PAI-1 monoclonal antibody was shown both to promote thrombolysis and to limit thrombus growth ${ }^{16)}$. In a second study a fragment of a polyclonal antibody against PAI-1 was reported to increase fibrinolysis ${ }^{17)}$. Compounds 1 and 2 inhibited PAI-1 activity in an amidolytic assay of tPA-mediated plasmin generation. These results were not due to a direct effect on IPA as the compounds did not enhance tPA activity in the absence of PAI-1. Although both compounds were poorly soluble in aqueous media $\mathbf{l}$ was selected for further evaluation as a higher concentration could be achieved. In a second amidolytic assay $\mathbf{1}$ also reversed the inhibitory effects of PAI-1 on urokinase and these data implied that the diketopiperazine was modulating the PAI-1: serine protease interaction possibly through interaction with the PAI-1 protein. In the light of the limited solubility of $\mathbf{1}$ the estimated $\mathrm{IC}_{50}$ values may be an underestimate due to precipitation of the compound in the in vitro assay buffer. Importantly 1 also enhanced fibrinolysis in an ex vivo assay of clot lysis in whole rat blood following intravenous bolus administration demonstrating that activity was retained in a more complex physiological medium ${ }^{18)}$. Compound 1 dose dependently increased clot lysis in blood from animals treated with the diketopiperazine compared to the vehicle group (Fig. 6). At $5 \mathrm{mg} / \mathrm{kg} 1$ increased clot lysis by $32.0 \pm 5.1 \%(\mathrm{n}=25, P<0.01)$. Finally an infusion of 1 effectively doubled the time to thrombus formation in the rat electrically stimulated carotid artery thrombosis model ${ }^{18)}$. An infusion of $1(1 \mathrm{mg} / \mathrm{kg} /$ minute, 20 minutes) significantly increased the time to vessel occlusion from $14.4 \pm 0.9$ minutes (vehicle, $10 \%$ Solutol in $0.9 \%$ saline, $\mathrm{n}=43)$ to $32.0 \pm 3.2$ minutes $(\mathrm{n}=19$, $P<0.01$ ). Compound 1 had comparable activity in this model to an infusion of the reference compound aspirin, which inhibits platelet aggregation. Importantly 1 at high concentration $(100 \mu \mathrm{M})$ had no effect on human platelet aggregation stimulated by collagen, ADP and sodium arachidonate (data not shown). Thus 1 appears to 
prolong the time to thrombus formation by a mechanism distinct from that of aspirin. Details of the pharmacological evaluation of 1 will be the subject of a further communication $^{18)}$.

As part of a screening programme we have identified a series of low molecular weight inhibitors of PAI-1 including compound 1. This diketopiperazine inhibited the PAI-1/tPA interaction in vitro, enhanced fibrinolysis ex vivo and protected against thrombus formation in the rat. These data demonstrate that a low molecular weight compound can modulate PAI-1 activity and these diketopiperazine compounds have provided an important chemical template for synthetic modification and optimisation. Ultimately, inhibitors of PAI-1 may have utility in the treatment of thromboembolic diseases, including deep vein thrombosis and unstable angina.

\section{Experimental}

General Procedures

NMR spectra were recorded on a Bruker AC400 spectrometer at $400 \mathrm{MHz}$. Chemical shifts were measured in ppm on the $\delta$ scale, downfield from tetramethylsilane as internal standard. Infra-red spectra were recorded on a Nicolet 5PC spectrophotometer. Mass spectra were obtained by desorption chemical ionisation $\left(\mathrm{NH}_{3}\right)$ or EI on a VG Trio 3 spectrometer. Accurate mass measurements were recorded on a VG Autospec spectrometer. Analytical TLC was carried out on Merck aluminium sheet silica gel $60 \mathrm{~F}_{254}$ plates. Anhydrous dimethylformamide was purchased from Aldrich and stored under nitrogen.

\section{Isolation of $\mathbf{1}$ and 2}

A 50 litre fermentation was centrifuged and the supernatant discarded. The resulting mycelium ( $c a .10 \mathrm{~kg}$ wet weight) was mixed briefly with methanol to remove any excess supernatant and then extracted with dichloromethane-methanol mixture $(1: 1)$ followed by dichloromethane. The extracts were pooled and evaporated under reduced pressure to dryness ( $\mathrm{ca} .10 \mathrm{~g}$ ).

A column (internal diameter $3.5 \mathrm{~cm}$, depth $25 \mathrm{~cm}$ ) was slurry packed with silica gel (Baker, 40 to $60 \mu \mathrm{m}$ ) in hexane. A solution of the crude extract in dichloromethane was dispersed in silica gel, the solvent removed and the remaining material applied to the column and eluted using a stepwise hexane/dichloromethane/ethyl acetate/methanol gradient increasing from $0 \%$ hexane to $100 \%$ methanol; $50 \times 50 \mathrm{ml}$ fractions were collected.

The fractions were concentrated to dryness, redissolved in $1 \%$ dichloromethane/methanol (volume varied from 5 to $15 \mathrm{ml}$ ) and monitored by high performance liquid chromatography and for PAI-inhibitory activity and those fractions containing the diketopiperazines were combined and concentrated to dryness. The residue was purified further by preparative HPLC using an octadecyl silica cartridge (Waters, $25 \times 100 \mathrm{~mm}$ Nova Pak HR $\mathrm{C}_{18}$ $6 \mu \mathrm{m}$ ) eluting at $12 \mathrm{ml} /$ minute with a solvent gradient programme commencing at $90 \%$ water $/ 10 \%$ acetonitrile and terminating at $100 \%$ acetonitrile after 20 minutes. The eluant was monitored at $350 \mathrm{~nm}$ and a peak eluting at ca 15 minutes was collected and evaporated at reduced pressure to yield a crude fraction containing the diketopiperazines (ca. $100 \mathrm{mg}$ ).

The crude fraction was chromatographed further by semi-preparative HPLC using an octadecyl silica cartridge (Waters, $8 \times 100 \mathrm{~mm} \mathrm{C}_{18}$ Nova Pak $4 \mu \mathrm{m}$ ). The fractions containing the diketopiperazines were concentrated to dryness to yield a white/yellow powder ( $c a$. $5 \mathrm{mg})$.

\section{tPA-Mediated Plasmin Generation Assay (S2251)}

This assay is a modification of the method of NILSSON et $a l^{19)}$ and utilises the COASET tPA kit (Chromogenix, Mölndal, Sweden). Briefly, the assay is as follows. Human PAI-1 was standardised by titration against $\mathrm{PAA}$. A concentration of PAI-1 was chosen that just inhibited tPA activity. The compounds were incubated with PAI-1 for 10 minutes prior to addition to the tPA assay system. Inhibition of PAI-1 activity resulted in tPA-mediated cleavage of plasminogen to plasmin. The plasmin released then cleaved the chromogenic substrate S2251 (H-D-ValLeu-Lys-pNA) (Chromogenix, Mölndal, Sweden) to produce $p$-nitroaniline which was detected spectrophotometrically at $405 \mathrm{~nm}$.

\section{Urokinase Assay (S2444)}

Human PAI-1 was standardised by titration against urokinase (human kidney cell, Sigma Chemical Co., UK) and the assay performed essentially by the method outlined above. Inhibition of PAI-1 activity resulted in cleavage of the chromogenic substrate S2444 (GluGlu-Arg-pNA $\cdot \mathrm{HCl}$ ) by urokinase and release of $p$ nitroaniline.

\section{Rat Dilute Blood Clot Lysis Time (DBCLT)}

The ex vivo DBCLT assay was performed as described $^{18)}$. Either vehicle $(10 \%$ Solutol in $0.9 \%$ saline $)$ or $1(1,2.5$ or $5 \mathrm{mg} / \mathrm{kg})$ was administered by single bolus injection via the tail vein to male Wistar rats. A blood sample was collected after 2.5 minutes, diluted $1: 4$ then ${ }^{125}$ I-fibrinogen added and the sample clotted by the addition of thrombin. Lysis was measured by the release of ${ }^{125} \mathrm{I}$-fibrin fragments into the supernatant.

\section{Synthesis}

\section{1,4-Diacetyl-2,5-piperazinedione (5)}

2,5-Piperazinedione $(200 \mathrm{~g}, 1.75 \mathrm{~mol})$ was heated at $130^{\circ} \mathrm{C}$ in acetic anhydride $(800 \mathrm{ml})$. After 6 hours the mixture was cooled to room temperature and the solvent removed under reduced pressure. The residue was recrystallised from a hexane - ethyl acetate mixture to give $294 \mathrm{~g}(85 \%)$ of a buff coloured solid. ${ }^{1} \mathrm{H} \mathrm{NMR}\left(\mathrm{CDCl}_{3}\right)$ : $\delta 2.59\left(3 \mathrm{H}, \mathrm{s}, \mathrm{COCH}_{3}\right) ; 4.58\left(2 \mathrm{H}, \mathrm{s}, \mathrm{CH}_{2}\right)$. MS (DCI $\left.\mathrm{NH}_{3}\right) m / z: 216\left(\left[\mathrm{MNH}_{4}\right]^{+}, 100 \%\right)$. IR ( $\mathrm{KBr}$ diffuse 
reflectance) $v_{\max }: 740,920,1250,1730,3000$. Microanalysis: calculated $\mathrm{C} 48.49 \%, \mathrm{H} 5.09 \%, \mathrm{~N} 14.14 \%$; found C $48.52 \%, \mathrm{H} 5.11 \%, \mathrm{~N} 14.12 \%$.

(3Z)-1-Acetyl-3-(4-methoxybenzylidene)-2,5piperazinedione (6)

A solution of 1,4-diacetyl-2,5-piperazinedione (5) (10 g, $50.5 \mathrm{mmol})$ and 4-methoxybenzaldehyde $(6.14 \mathrm{ml}, 50.5$ mmol) in dry tetrahydrofuran $(100 \mathrm{ml})$ was cooled to $0^{\circ} \mathrm{C}$. A solution of potassium $t$-butoxide $(5.67 \mathrm{~g}$, $50.5 \mathrm{mmol})$ in $t$-butanol $(100 \mathrm{ml})$ was then added dropwise over 30 minutes. After the addition was complete the mixture was allowed to warm to room temperature overnight. The mixture was diluted with ethyl acetate $(400 \mathrm{ml})$ and washed with water $(2 \times 200 \mathrm{ml})$ and saturated brine $(2 \times 200 \mathrm{ml})$. The white precipitate which formed in the organic phase during this process was filtered off and dried to give $9.55 \mathrm{~g}(69 \%)$ of a white solid. ${ }^{1} \mathrm{H} \mathrm{NMR}\left(\mathrm{CDCl}_{3}\right): \delta 2.66\left(3 \mathrm{H}, \mathrm{s}, \mathrm{COCH}_{3}\right) ; 3.85$ $\left(3 \mathrm{H}, \mathrm{s}, \mathrm{OCH}_{3}\right) ; 4.53(2 \mathrm{H}, \mathrm{s}, \mathrm{CH}) ; 6.98(2 \mathrm{H}, \mathrm{d}, J=8 \mathrm{~Hz}$, Ar); 7.14 (1H, s, vinylic); $7.47(2 \mathrm{H}, \mathrm{d}, J=8 \mathrm{~Hz}, \mathrm{Ar}) ; 7.90$ $\left(1 \mathrm{H}\right.$, brs, NH). MS (DCI NH $\mathrm{NH}_{3} \mathrm{~m} / z: 275\left(\mathrm{MH}^{+}, 100 \%\right)$. IR (KBr diffuse reflectance) $v_{\text {max }}: 740,1230,1380,1740$, 3000, 3220. Microanalysis: calculated C $61.31 \%, \mathrm{H}$ $5.14 \%$, N $10.21 \%$; found C $61.29 \%$, H $5.13 \%$, N $10.20 \%$.

(3Z)-1-Acetyl-3-(4-methoxybenzylidene)-4-methyl2,5-piperazinedione (7)

A mixture of (3Z)-1-acetyl-3-(4-methoxybenzylidene)2,5-piperazinedione (6), methyl iodide $(1.71 \mathrm{ml}, 27.4$ $\mathrm{mmol})$ and sodium carbonate $(1.93 \mathrm{~g}, 18.25 \mathrm{mmol})$ in dry dimethylformamide $(100 \mathrm{ml})$ was stirred at room temperature for 4 days. After 4 days TLC (ethyl acetate hexane $1: 1$ ) indicated that no starting material remained. The mixture was diluted with ethyl acetate $(750 \mathrm{ml})$ and washed with saturated brine $(4 \times 300 \mathrm{ml})$. The organic phase was dried $\left(\mathrm{MgSO}_{4}\right)$ and the solvent removed under reduced pressure. The residue was purified by flash chromatography (silica, eluting with ethyl acetate: hexane $1: 2$, then with ethyl acetate : hexane $1: 1)$ to give $4.62 \mathrm{~g}(88 \%)$ of a yellow solid. ${ }^{1} \mathrm{H} \mathrm{NMR}\left(\mathrm{CDCl}_{3}\right)$; $\delta 2.64\left(3 \mathrm{H}, \mathrm{s}, \mathrm{COCH}_{3}\right) ; 2.96\left(3 \mathrm{H}, \mathrm{s}, \mathrm{N}-\mathrm{CH} H_{3}\right) ; 3.85(3 \mathrm{H}, \mathrm{s}$, $\left.\left.\mathrm{OCH}_{3}\right) ; 4.52(2 \mathrm{H}, \mathrm{s}, \mathrm{CH})_{2}\right) 6.90(2 \mathrm{H}, \mathrm{d}, J=8 \mathrm{~Hz}, \mathrm{Ar})$; $7.25\left(3 \mathrm{H}, \mathrm{m}, \mathrm{Ar}\right.$ and vinylic). MS (DCI $\left.\mathrm{NH}_{3}\right) m / z: 306$ $\left(\left[\mathrm{MNH}_{4}\right]^{+}, 32 \%\right) ; 289\left(\mathrm{MH}^{+}, 100 \%\right)$. IR (KBr diffuse reflectance) $v_{\max }: 730,910,1730,1735,3000$. Micro-

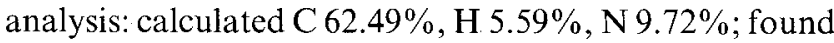
C $62.48 \%$, H $5.58 \%$, N $9.68 \%$.

(3Z,6Z)-3-Benzylidene-6-(4-methoxybenzylidene)-1methyl-2,5-piperazinedione (2)

A mixture of (3Z)-1-acetyl-3-(4-methoxybenzylidene)4-methyl-2,5-piperazinedione (7) $(4.47 \mathrm{~g}, 15.5 \mathrm{mmol})$ caesium carbonate $(6.03 \mathrm{~g}, 18.5 \mathrm{mmol})$ and benzaldehyde $(1.58 \mathrm{ml}, 15.5 \mathrm{mmol})$ in dry DMF $(90 \mathrm{ml})$ was heated at $80^{\circ} \mathrm{C}$. After 2 hours TLC dichloromethane:methanol $50: 1)$ showed no starting material remained. The mixture was cooled to room temperature and poured into ethyl acetate $(500 \mathrm{ml})$. The organic solution was washed with saturated brine $(3 \times 200 \mathrm{ml})$, dried $\left(\mathrm{MgSO}_{4}\right)$ and the solvent removed under reduced pressure. The residue was triturated with methanol to give $2.80 \mathrm{~g}(54 \%)$ of a pale yellow solid. A sample was recrystallised from ethanol for analysis. ${ }^{1} \mathrm{H} \mathrm{NMR}\left(\mathrm{CDC}_{3}\right) \delta 3.03\left(3 \mathrm{H}, \mathrm{s}, \mathrm{N}-\mathrm{CH}_{3}\right)$; $3.85\left(3 \mathrm{H}, \mathrm{s}, \mathrm{OCH}_{3}\right) ; 6.95(2 \mathrm{H}, \mathrm{d}, J=8 \mathrm{~Hz}, \mathrm{Ar}) ; 7.09(1 \mathrm{H}$, $\mathrm{s}$, vinylic); $7.22(1 \mathrm{H}, \mathrm{s}$, vinylic); $7.30 \sim 7.50(7 \mathrm{H}, \mathrm{m}, \mathrm{Ar})$; $8.01(1 \mathrm{H}, \text { br s, NH). MS (DCI NH })_{3} m / z: 335\left(\mathrm{MH}^{+}\right.$, $100 \%$ ). IR ( $\mathrm{KBr}$ diffuse reflectance) $v_{\text {max }}: 740,910,1390$, 1720, 3000, 3400. Microanalysis: calculated C 71.84\%, H $5.43 \%$, N $8.38 \%$; found C $71.81 \%$, H $5.31 \%$, N $8.31 \%$.

(3Z,6Z)-3-(4-Methoxybenzylidene)-6-benzylidene-2,5piperazinedione (1)

A mixture of (3Z)-1-acetyl-3-(4-methoxybenzylidene)2,5-piperazinedione (6) $(5.0 \mathrm{~g}, 18.25 \mathrm{mmol})$ caesium carbonate $(5.95 \mathrm{~g}, 18.25 \mathrm{mmol})$ and benzaldehyde $(1.85$ $\mathrm{ml}, 18.25 \mathrm{mmol})$ in dimethylformamide $(50 \mathrm{ml})$ was heated at $90^{\circ} \mathrm{C}$. After 2 hours the mixture was cooled to room temperature, diluted with ethyl acetate $(100 \mathrm{ml})$ and poured into water $(100 \mathrm{ml})$. The resultant precipitate was collected by filtration, washed with water followed by methanol and diethyl ether and recrystallised from acetic acid to give $4.0 \mathrm{~g}(67 \%)$ of a yellow solid. ${ }^{1} \mathrm{H}$ NMR ( $d_{6}$-DMSO): $\delta 3.78\left(3 \mathrm{H}, \mathrm{s}, \mathrm{OCH}_{3}\right) ; 6.74(1 \mathrm{H}, \mathrm{s}$, vinylic); $6.75(1 \mathrm{H}, \mathrm{s}$, vinylic); $6.98(2 \mathrm{H}, \mathrm{d}, J=8 \mathrm{~Hz}, \mathrm{Ar}) ; 7.32(1 \mathrm{H}$, $\mathrm{m}, \mathrm{Ar}) ; 7.40(2 \mathrm{H}, \mathrm{m}, \mathrm{Ar}) ; 7.54(4 \mathrm{H}, \mathrm{m}, \mathrm{Ar}) ; 10.16(1 \mathrm{H}$, brs, $\mathrm{NH})$. MS (DCI $\left.\mathrm{NH}_{3}\right) m / z: 321\left(\mathrm{MH}^{+}, 36 \%\right) ; 160$ $(100 \%)$. IR ( $\mathrm{KBr}$ diffuse reflectance) $v_{\max }: 730,1010$, $1230,1405,1720,1735,3000,3200$. Microanalysis: calculated $\mathrm{C} 71.24 \%, \mathrm{H} 5.03 \%, \mathrm{~N} 8.74 \%$, found $\mathrm{C}$ $71.27 \%$, H $5.01 \%$, N $8.72 \%$.

\section{Acknowledgements}

The authors would like to thank Julian Abery, Fiona Bent, Liam Evans, Trevor Gibson, Mo Latif, Neil Porter and Diane Wilkinson for their contributions to these studies.

\section{References}

1) Krishnamurti, C. \& B. M. Alving: Plasminogen activator inhibitor type 1: biochemistry and evidence for modulation of fibrinolysis in vivo. Seminars in Thrombosis and Haemostasis 18: 67 80, 1992

2) Huber, R. \& R. W. Carrell: Implications of the three-dimensional structure of alpha 1-antitrypsin for the structure and function of serpins. Biochemistry 28: $8951 \sim 8966,1989$

3) Ny, T.; M. Sawdey, D. Lawrence, J. L. Millan \& D. J. LoskuTOFF: Cloning and sequence of a cDNA coding for the human beta-migrating endothelial-cell-type plasminogen activator inhibitor. Proc. Natl. Acad. Sci. U.S.A. $83: 6776 \sim 6780,1986$

4) Lindahl, T. L.; P. I. Ohlsson \& B. Wiman: The mechanism of the reaction between human plasminogenactivator inhibitor 1 and tissue plasminogen activator. Biochem. J. 265: 109 113, 1990

5) Erickson, L. A.; G. J. Fici, J. E. Lund, T. P. Boyle, H 
G. Polites \& K. R. Marotti: Development of venous occlusions in mice transgenic for the plasminogen activator inhibitor-1 gene. Nature 346: 74 76, 1990

6) Dawson, S. \& A. HENnEy: The status of PAI-1 as a risk factor for arterial and thrombotic disease: a review. Atherosclerosis 95: 105 117, 1992

7) Collins, M. A. D.; M. I. Chicarelli-Robinson, J. S Bryans, S. J. Brocchini, C. J. Latham \& J. R. Shaw (Xenova Limited): Pharmaceutically active diketopiperazines. WO 94/04512, March 3, 1994

8) Gerber, N. N.: Phenazines, phenoxazinones, and dioxopiperazines from Streptomyces thioluteus. J. Org. Chem. 32: 4055 4059, 1967

9) Shin, C.; M. Hayakawa, H. Kato, K. Mikani \& J. YoSHIMURA: $\alpha, \beta$-Unsaturated carboxylic acid derivatives. 18. Syntheses of geometric isomers of 3,6-dibenzylideneand 3-p-anisylidene-6-benzylidene-2, 5-piperazinediones. J. Chem. Soc. Perkin Trans. 1: 419 421, 1980

10) Shin, C.; Y. Sato, M. Hayakawa, M. Kondo \& J. YosHimuRA: $\alpha, \beta$-Unsaturated carboxylic acid derivatives 20. $N$-Methylation of $\alpha$-dehydroamino acid ester and its cyclic dipeptide from various routes, Heterocycles 16: $1573 \sim 1578,1981$

11) PoJer, P. M.: Mild catalytic hydrogenation of carboncarbon multiple bonds. Chemistry and Industry: 177 178,1986

12) Yokol, T.; L. M. Yang, T. Yokol, R. Y. WU \& K. H. LEE: Neihumicin, a new cytotoxic antibiotic from Micromonospora neihuensis. J. Antibiotics 41: 494 501, 1988

13) Williams, S. T.; M. Goodfellow, E. M. H. Wellington,
J. C. Vickers, G. Alderson, P. H. A. Sneath, M. J. SACKIN \& A. M. Mortimer: A probalitity matrix for identification of streptomycetes. J. Gen. Microbiol. 129: $1815 \sim 1830,1983$

14) Williams, S. T.; M. Goodfellow, G. Alderson, E. M. H. Wellington, P. H. A. Sneath \& M. J. Sackin: Numerical classification of Streptomyces and related genera. J. Gen. Microbiol. 129: 1743 1813, 1983

15) Declerk, P. J.; I. Juhan-Vague, J. Felez \& B. Wiman: Pathophysiology of fibrinolysis. Journal of Internal Medicine 236: 425 432, 1994

16) Levi, M.; B. J. Biemond, A. J. van Zonneveld, J. W. Ten Cate \& H. Pannekoek: Inhibition of plasminogen activator inhibitor-1 activity results in promotion of endogenous thrombolysis and inhibition of thrombus extension in models of experimental thrombosis. Circulation 85: 305 312, 1992

17) Abrahamsson, T.; P. Buörquist, J. Deinum, J. Ehnebom, M. Hulander, A, Legnehed, C. Matsson, V. Nerme, A. Westin-EriksSON \& B. Akerblom: An antibody fragment against PAI-1 inhibits PAI-1 activity and stimulates fibrinolysis in vitro and in vivo. Fibrinolysis 8 (Suppl. 2): 55 56, 1994

18) Charlton, P.; R. Faint, F. Bent, J. Bryans, I. Chicarelli-Robinson, I. Mackie, S. Machin \& P. BEVAN: Evaluation of a low molecular weight modulator of human plasminogen activator inhibitor-1 activity. Thombosis and Haemostasis 75: 808 815, 1996

19) Nilsson, K.; S. Rosén \& P. Friberger: A new kit for the determination of tissue plasminogen activator and its inhibitor in blood. Fibrinolysis 1: $163 \sim 168,1987$ 